Verfügbar unter / Available at:

https://hdl.handle.net/20.500.11970/100207

Vorgeschlagene Zitierweise / Suggested citation:

Benedict, Stephen T.; Caldwell, Andral W. (2010): Trends in Live-Bed Pier Scour at Selected Bridges in South Carolina. In: Burns, Susan E.; Bhatia, Shobha K.; Avila, Catherine M. C.; Hunt, Beatrice E. (Hg.): Proceedings 5th International Conference on Scour and Erosion (ICSE-5), November 7-10, 2010, San Francisco, USA. Reston, Va.: American Society of Civil Engineers. S. 95-104. 


\title{
Trends in Live-Bed Pier Scour at Selected Bridges in South Carolina
}

\author{
Stephen T. Benedict ${ }^{1}$ and Andral W. Caldwell ${ }^{2}$
}

\author{
${ }^{1}$ Hydrologist, U.S. Geological Survey, 405 College Avenue, Clemson, SC 29631; \\ email: benedict@usgs.gov \\ ${ }^{2}$ Hydrologist, U.S. Geological Survey, 720 Gracern Road, Columbia, SC 29210; \\ email: acaldwel@usgs.gov
}

\begin{abstract}
The U.S. Geological Survey, in cooperation with the South Carolina Department of Transportation, used ground-penetrating radar to collect measurements of live-bed pier scour at 78 bridges in the Piedmont and Coastal Plain physiographic provinces of South Carolina. The 141 measurements of live-bed pier-scour depth ranged from 0.5 to 5.1 meters. Using hydraulic data estimated with a one-dimensional flow model, predicted live-bed scour depths were computed with scour equations from the Hydraulic Engineering Circular 18 and compared with measured scour. This comparison indicated that predicted pier-scour depths generally exceeded the measured pier-scour depths. At times, predicted pier-scour depths were excessive with overpredictions as large as 7.0 meters. Relations in the live-bed pier-scour data also were investigated, leading to the development of an envelope curve for assessing the upper-bound of live-bed pier scour using pier width as the primary explanatory variable. The envelope curve developed with the field data has limitations, but it can be used as a supplementary tool for assessing the potential for live-bed pier scour in South Carolina. This paper will present findings related to the field investigation of live-bed pier scour. A companion paper presents findings related to live-bed contraction scour that was studied during the same field investigation.
\end{abstract}

\section{INTRODUCTION}

The U.S. Geological Survey (USGS), in cooperation with the South Carolina Department of Transportation (SCDOT), investigated historic scour at 235 bridges in the Piedmont and Coastal Plain physiographic provinces of South Carolina (Benedict, 2003; Benedict and Caldwell, 2006; Benedict and Caldwell, 2009). The general objectives of these studies were to (1) collect field measurements of historic abutment, contraction, and pier scour at sites that could be associated with major floods, (2) use the field data to assess the performance of the scour-prediction equations listed in the Federal Highway Administration Hydraulic Engineering Circular No. 18 (HEC-18) (Richardson and Davis, 2001), and (3) develop regional envelope curves to help assess scour potential in the Piedmont and Coastal Plain regions of South Carolina. The Piedmont and Coastal Plain regions have distinctive hydraulic and soil characteristics that could produce differing scour responses and therefore, the data within these regions were initially evaluated as separate data sets.

These investigations led to the development of a suite of field-derived envelope curves that provide supplementary tools to assist practitioners in South Carolina to assess scour potential for various scour components. Additionally, they have led to the development of large databases that are useful in assessing the general 
trends of various scour-prediction equations. While there are limitations associated with the South Carolina field data, the large number of data provides a useful means for assessing equation and field trends. The first two field investigations in South Carolina (Benedict, 2003; Benedict and Caldwell, 2006) focused on the occurrence of historic clear-water abutment, contraction, and pier scour on bridge overbanks. Clear-water scour typically occurs on the overbanks of a bridge because upstream floodplain flows do not transport bed sediments into the area of scour. Such conditions provide a readily measured record of historic scour. In contrast, the most recent field investigation (Benedict and Caldwell, 2009) focused on the occurrence of historic live-bed contraction and pier scour. Live-bed scour typically occurs in the main channel at a bridge where bed sediments are transported into the area of scour thus partially or totally refilling the scour holes as flood waters recede. This paper presents findings related to live-bed pier scour. A companion paper presents findings regarding live-bed contraction scour in South Carolina. For expanded details regarding this investigation refer to Benedict and Caldwell (2009).

\section{FIELD DATA}

A primary objective of the investigation by Benedict and Caldwell (2009) was to develop a database of live-bed pier-scour field measurements that could be used to assess regional scour trends in South Carolina as well as evaluate the performance of the HEC-18 (Richardson and Davis, 2001) pier-scour equation. When using field data for such purposes, it is important to understand the data characteristics and limitations. Therefore, a brief summary of the field data used in the investigation will be presented.

Live-bed pier-scour holes in South Carolina occur in the main channel of streams and are typically inundated and partially or totally refilled with sediments, making the measurement of these scour holes problematic. Therefore, to measure historic live-bed pier scour under these field conditions, a ground-penetrating radar (GPR) system deployed by boat was utilized. Ground penetrating radar has been used successfully to locate and estimate scour depths associated with historic live-bed scour (Placzek and Haeni, 1995; Webb and others, 2000) and the shallow (6 meters or less) freshwater granular bottom streams of South Carolina provide a favorable environment for the application of GPR. (See Benedict and Caldwell (2009) for details regarding the application and limitations of GPR for the investigation.) To provide some assurance that measured historic scour in this investigation would reflect scour resulting from high flows, USGS streamflow gaging records were reviewed and a strategic set of 78 bridge sites located in the Coastal Plain and Piedmont physiographic provinces of South Carolina were selected for data collection (Figure 1). The set included older bridges that likely had undergone a large flood (the bridge age ranged from 6 to 105 years with a median of 56) and bridges known to have experienced larger floods, with 48 sites having historic floods near to or exceeding the 1-percent exceedance flow. One-hundred and forty-one measurements of historic live-bed pier scour were collected in the investigation with 99 measurements collected in the Coastal Plain with scour depths ranging from 0.5 to 5.1 meters and 42 measurements collected in the Piedmont with scour depths ranging from 0.2 to 0.8 meters. The streams of the Coastal Plain and Piedmont physiographic provinces have regional characteristics, with the Coastal Plain streams tending to 


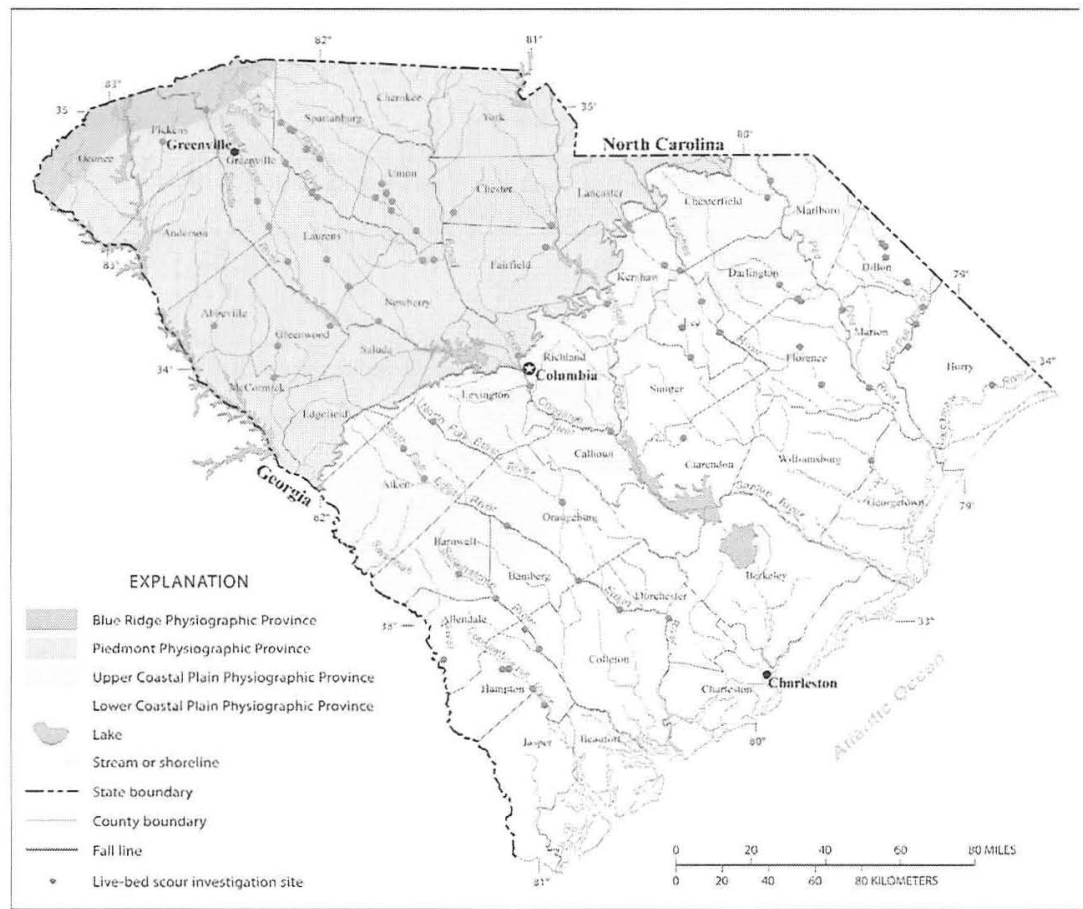

Figure 1. Location of live-bed pier-scour sites in South Carolina.

have lower gradients, lower flow velocities, and longer flood-flow durations in contrast to the Piedmont streams. Table 1 presents the minimum, maximum, and median values of selected stream characteristics in this investigation and highlights the differing stream trends for the two regions. Because of the differing regional characteristics, the Coastal Plain and Piedmont data were initially analyzed as separate data sets to determine if significant regional trends existed. The analysis indicated that the regional distinctions were insignificant and the data for these regions were combined for the development of the South Carolina live-bed pier-scour envelope curve.

To supplement the South Carolina field data, 92 field measurements of livebed pier scour from the USGS National Bridge Scour Database (NBSD; U.S. Geological Survey, 2001; Table 1) having similar characteristics to the South Carolina data were used. These data included measurements at 16 bridges in 9 States (Alaska, Arkansas, Colorado, Georgia, Indiana, Louisiana, Ohio, Minnesota, and Missouri). Most of the NBSD scour data were collected during high-flow events and measurements of the flow were often taken concurrently with the scour measurements. The supplementary field data only were used to verify trends in the field envelope curves. 
Table 1. Range of Selected Parameters for Field Measurements of Pier Scour

\begin{tabular}{|c|c|c|c|c|c|c|c|}
\hline $\begin{array}{c}\text { Range } \\
\text { value }\end{array}$ & $\begin{array}{c}\text { Drainage } \\
\text { area } \\
\text { (square } \\
\text { kilometer) }\end{array}$ & $\begin{array}{c}\text { Channel } \\
\text { slope } \\
\text { (meters/ } \\
\text { meter) }\end{array}$ & $\begin{array}{l}\text { Average } \\
\text { approach } \\
\text { velocity } \\
\text { (meters/ } \\
\text { second) }\end{array}$ & $\begin{array}{c}\text { Average } \\
\text { approach } \\
\text { depth } \\
\text { (meters) }\end{array}$ & $\begin{array}{c}\text { Pier width } \\
\text { (meters) }\end{array}$ & $\begin{array}{c}\text { Median } \\
\text { grain } \\
\text { size } \\
\text { (milli- } \\
\text { meter) }\end{array}$ & $\begin{array}{c}\text { Measured } \\
\text { pier-scour } \\
\text { depth } \\
\text { (meters) }\end{array}$ \\
\hline \multicolumn{8}{|c|}{$\begin{array}{l}\text { South Carolina Live-Bed Pier-Scour Data -- Piedmont (Benedict and Caldwell, 2009) } \\
\text { (42 measurements) }\end{array}$} \\
\hline Minimum & 54.4 & 0.0002 & 0.5 & 2.1 & 0.2 & 0.5 & 0.6 \\
\hline Median & 383 & 0.0070 & 2.2 & 5.9 & 1.2 & 1.0 & 1.4 \\
\hline Maximum & 13,600 & 0.0016 & 2.9 & 8.3 & 1.8 & 1.7 & 2.7 \\
\hline \multicolumn{8}{|c|}{$\begin{array}{l}\text { South Carolina Live-Bed Pier-Scour Data -- Coastal Plain (Benedict and Caldwell, 2009) } \\
\text { (99 measurements) }\end{array}$} \\
\hline Minimum & 44.5 & 0.0001 & 0.2 & 0.9 & 0.3 & 0.2 & 0.5 \\
\hline Median & 2,670 & 0.0003 & 1.3 & 4.8 & 0.5 & 0.6 & 1.2 \\
\hline Maximum & 24,200 & 0.0020 & 2.7 & 15.5 & 2.7 & 1.7 & 5.1 \\
\hline \multicolumn{8}{|c|}{$\begin{array}{l}\text { National Field Data (U.S. Geological Survey, 2001) } \\
\text { (92 measurements) }\end{array}$} \\
\hline Minimum & $1,200^{\mathrm{a}}$ & $0.0001^{b}$ & 0.3 & 0.5 & 0.8 & 0.1 & 0.2 \\
\hline Median & 95,300 & 0.0002 & 1.4 & 7.7 & 2.8 & 0.5 & 1.4 \\
\hline Maximum & $1,800,000$ & 0.0010 & 3.9 & 20.0 & 5.5 & 1.8 & 7.7 \\
\hline
\end{tabular}

${ }^{\text {a }}$ Drainage areas for 3 of the 16 bridge sites were not available.

${ }^{\mathrm{b}}$ Channel slopes for 6 of the 16 bridge sites were not available.

The field measurements used in this investigation provide a large set of historic live-bed pier-scour data offering a valuable resource for gaining insights to scour trends within the field. However, the limitations of these data must be kept in mind when using the data to assess scour trends. Some of these limitations for the South Carolina data include (1) errors associated with GPR measurements and interpretations, (2) field complexities that may limit the ability to properly measure and (or) interpret the scour data, (3) field complexities that may produce scour anomalies, and (4) errors associated with hydraulic estimates from flow models. The noted limitations associated with the South Carolina live-bed pier-scour data will introduce error into the analysis for this investigation, making the data less than ideal. However, the large number of field measurements, in conjunction with the NBSD data, provides a means for evaluating the general trends of live-bed pier scour in South Carolina.

\section{COMPARISON WITH LABORATORY DATA}

Figure 2 shows the South Carolina live-bed pier-scour data and the laboratory data used to develop the original HEC-18 pier-scour equation (Richardson and others, 1991) plotted in a dimensionless format. (Note: Field measurements with pier skews were excluded in Figure 2.) The trend line through the laboratory data represents the original HEC-18 pier-scour equation in a power function format. The South Carolina live-bed pier-scour data have a larger scatter than that of the laboratory data; however, the trend line for the field data is similar to that of the laboratory data, indicating that the South Carolina field data are capturing the anticipated trends. This 


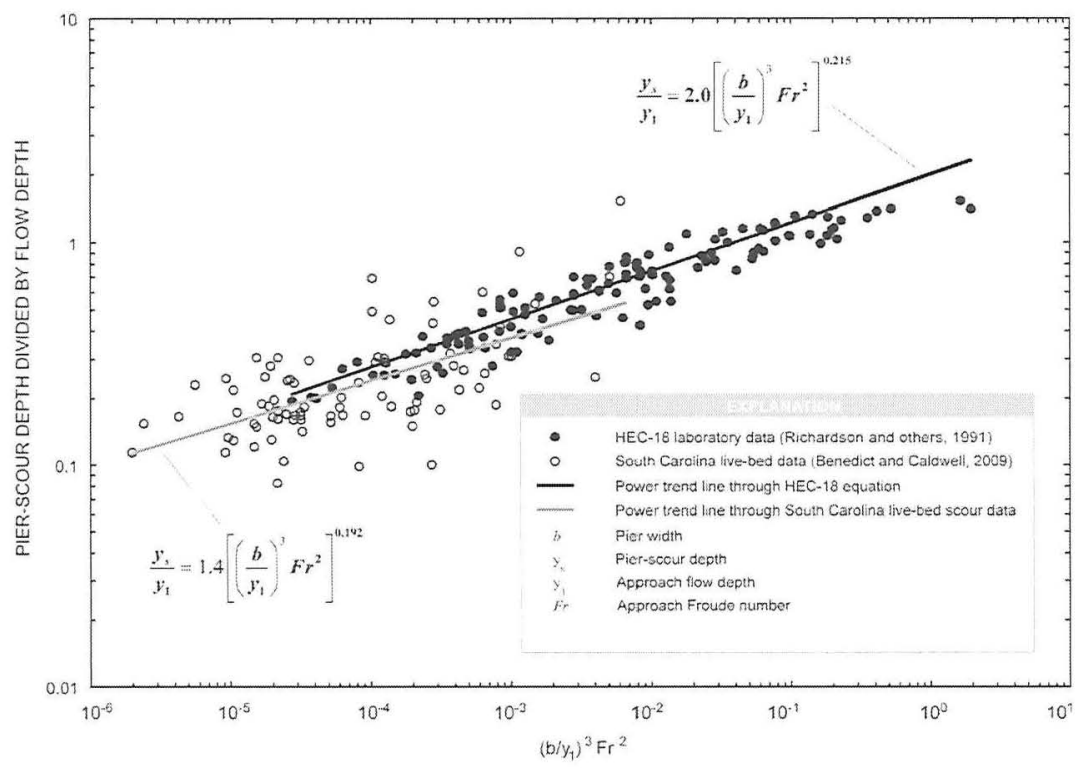

Figure 2. Relation of relative scour $\left(y_{s} / y_{1}\right)$ to the dimensionless variable, $\left(b / y_{1}\right)^{3} \mathrm{Fr}^{2}$, for laboratory data used to develop the original HEC-18 pier-scour equation (Richardson and others, 1991) and data from selected sites in South Carolina (from Benedict and

Caldwell (2009)).

provides confidence that the South Carolina live-bed pier-scour data are reasonable and therefore can be used to assess the performance of scour-prediction equations to develop regional envelope curves.

\section{EVALUATION OF HEC-18 EQUATION}

To predict live-bed pier-scour depth, Richardson and Davis (2001) recommend using the following equation that initially was derived from laboratory data for noncohesive sediments and later was modified with correction coefficients to account for coarse sediments and wide piers.

$$
\frac{y_{s}}{b}=2.0 K_{1} K_{2} K_{3} K_{4}\left[\frac{y_{1}}{b}\right]^{0.35} F r_{1}^{0.43},
$$

where

$y_{S}$ is the predicted pier-scour depth, in meters;

$b$ is the pier width, in meters;

$K_{I}$ is the dimensionless correction coefficient for pier-nose shape;

$K_{2}$ is the dimensionless correction coefficient for flow angle of attack;

$K_{3}$ is the dimensionless correction coefficient for streambed conditions; 
$K_{4}$ is the dimensionless correction coefficient for streambed armoring;

$y_{l}$ is the approach-flow depth, in meters; and

$\mathrm{Fr}_{l}$ is the approach-flow Froude number defined as

where

$$
F r_{1}=V_{1} /\left(g y_{1}\right)^{0.5}
$$

$V_{l}$ is the mean approach velocity, in meters per second; and

$g$ is the acceleration of gravity, in meters per square second.

Using hydraulic variables estimated from a one-dimensional model with the estimated historic flows, predicted pier-scour depths were computed using equation 1. Twenty-five of the 141 pier-scour measurements required a complex pier-scour computation as described in HEC-18 (Richardson and Davis, 2001), and at these piers, both the standard (eq. 1) and complex pier-scour computations were made. Predicted pier-scour depths were compared with measured pier-scour depths for the Coastal Plain and Piedmont regions, as shown in Figure 3. Figure 3A shows the results of predicted scour based on the standard pier-scour computation (eq. 1), and Figure $3 \mathrm{~B}$ includes data from the 25 complex pier computations. The trends of Figure $3 \mathrm{~A}$ indicate that the standard HEC-18 pier-scour equation (eq. 1) underpredicts approximately 16 percent of the data, with underprediction ranging from 0.03 to 1.0 meter with a median value of 0.2 meter. The frequency of overprediction is approximately 84 percent of the data, with overprediction ranging from 0.03 to 4.1 meters with a median value of 0.6 meter. Benedict and Caldwell (2006) and Mueller and Wagner (2005) noted similar trends for clear-water pier scour in South Carolina and selected data from the NBSD (U.S. Geological Survey, 2001), respectively, with slightly lower rates of underprediction. The higher rate of underprediction for the South Carolina live-bed data can be attributed, in part, to the potential error associated with the GPR data collection and interpretation. Figure 3B includes predicted scour associated with the 25 complex pier-scour computations and indicates that when this procedure is applied to complex piers, it tends to produce larger estimates of scour than the standard equation (eq. 1). Based on the results of Figure 3 and those of Benedict and Caldwell (2006) and Mueller and Wagner (2005), it is reasonable to conclude that using the HEC-18 standard and complex pier-scour equation generally provides conservative estimates of pier scour that, at times, can produce excessive overprediction (as large as 7 meters in Benedict and Caldwell (2009)) with occasional underprediction.

\section{ENVELOPE CURVES}

Benedict (2007) provides an overview for the development of regional bridgescour envelope curves and lists the assumptions and supporting justification on which they are derived. These assumptions include, (1) scour is influenced by the hydrology and geology of a physiographic region, and therefore, will display regional trends, (2) just as there are limits to maximum scour depth within laboratory data there will be limits in field data that can be used to form an upper-bound envelope curve of historic scour, and (3) scour has a strong correlation to geometric variables, such as pier width and the geometric contraction ratio, and these geometric variables 

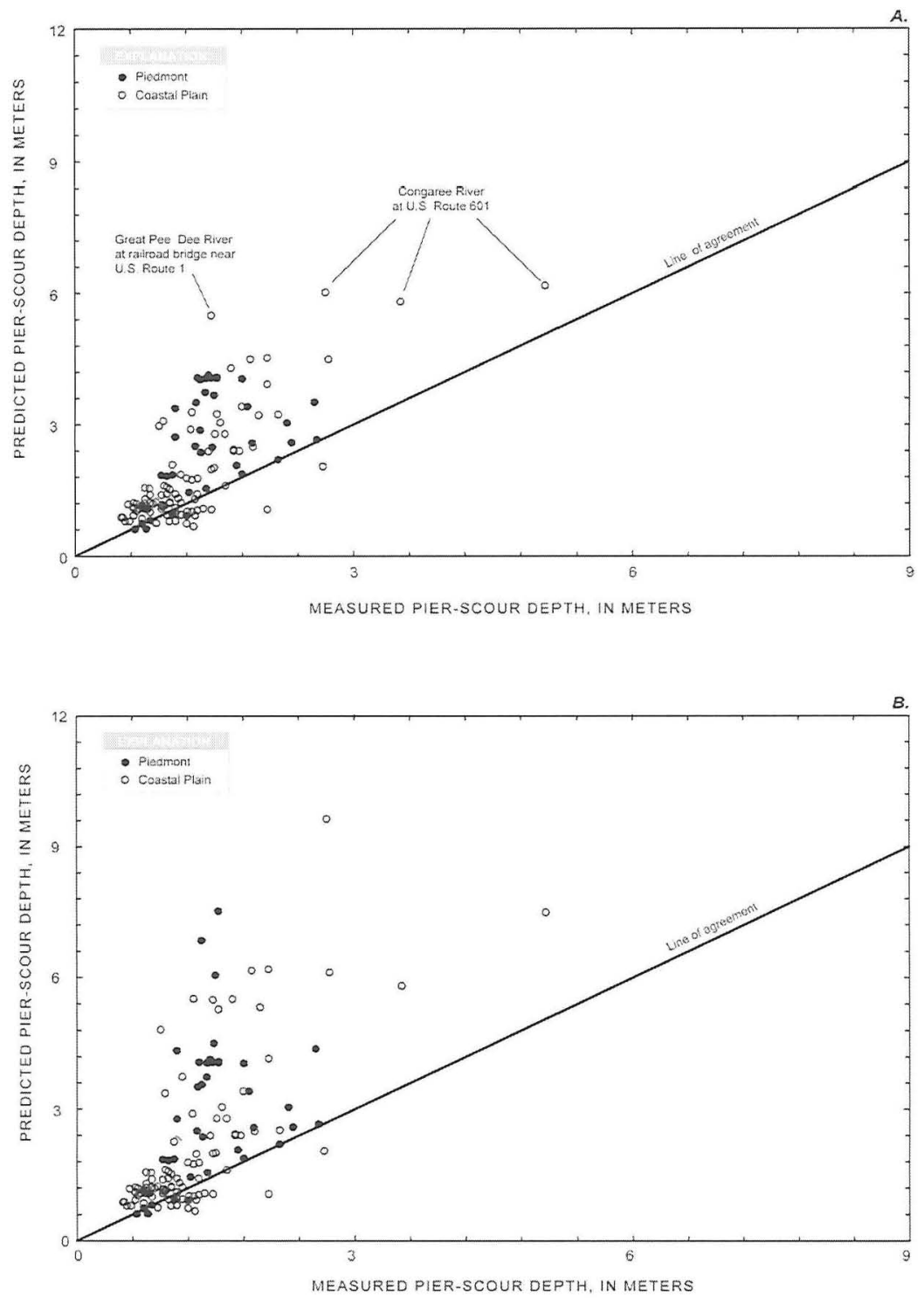

Figure 3. Relation of measured live-bed pier-scour depth to predicted pier-scour depth

(A) neglecting the complex pier computation and (B) using the complex pier computation for the maximum historic flows at selected sites in South Carolina (from Benedict and Caldwell (2009)). 


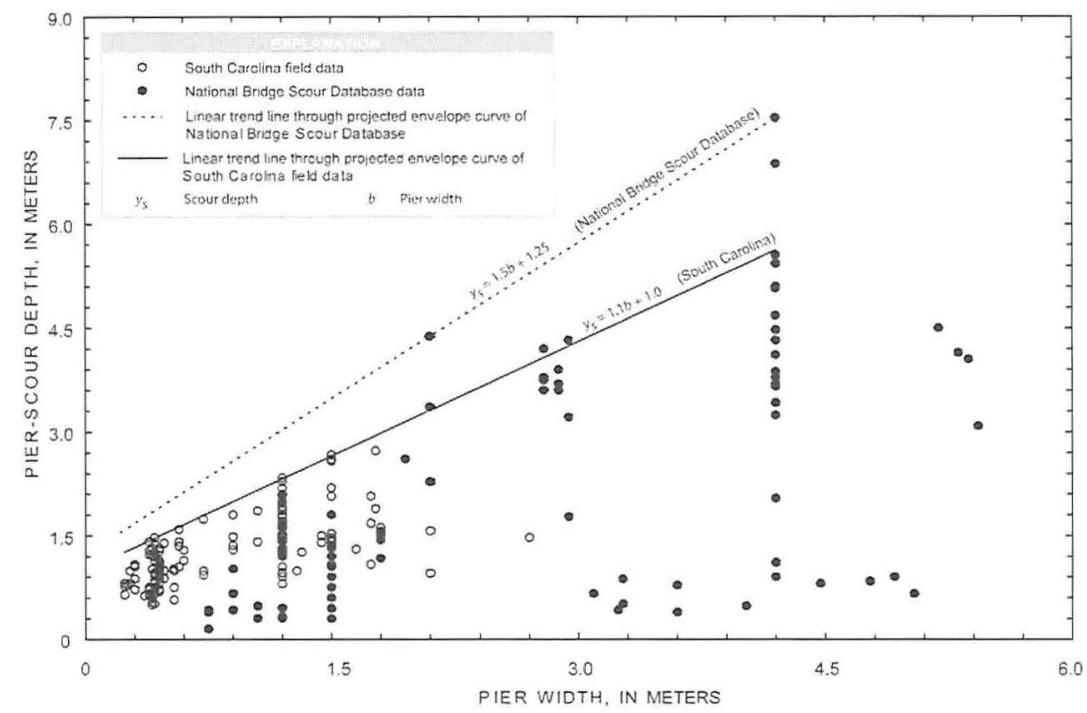

Figure 4. Envelope curves for pier-scour depth for selected field data (modified from Benedict and Caldwell (2009)).

can be used as the explanatory variable to develop simple but useful regional bridgescour envelope curves. These assumptions formed the foundation for developing the South Carolina live-bed pier-scour envelope curves.

In developing bridge-scour envelope curves, an appropriate geometric variable that is strongly correlated to the scour component of interest must be selected for use as an explanatory variable. In the case of pier scour, scour depth will be strongly correlated to pier width (Laursen and Toch, 1956; Melville and Coleman, 2000; Richardson and Davis, 2001; Mueller and Wagner, 2005). The envelope curves in Figure 4 show the upper-bound trends for the relation of measured pierscour depth and pier width for the South Carolina and NBSD data. (Note: Field measurements with significant skews were excluded from Figure 4.) The field envelope curves and their associated equations have similar quantitative trends with an increase in the upper bound of scour with increasing pier width. Benedict and Caldwell (2009) compared these field envelope curves with envelope curves for selected laboratory data. While the quantitative values between field and laboratory varied, the qualitative trends were very similar indicating that the trends for the field data are reasonable.

Laboratory investigations note that the system of vortices generated by flow around a pier is the mechanism that produces pier scour. The dominant factors within this system that contribute to scour production are the downflow at the face of the pier and the horseshoe vortex at the base of the pier (Melville and Coleman, 2000). Hydraulic, soil, and geometric characteristics will influence the magnitude of scour produced by the system of vortices, with pier width having a prominent and 
proportional influence. Therefore, as pier width increases, and other variables remain constant, there will be a proportional increase in scour depth. The patterns displayed by the envelope curves in Figure 4 are consistent with laboratory findings further confirming that the trends for the field data are reasonable.

The majority of the NBSD data falls within, or is very close to, the South Carolina envelope curve. The three measurements that significantly exceed the envelope curve (Figure 4) are associated with large rivers having drainage areas that range from 135,000 to 157,000 square kilometers, which are significantly greater than the basin sizes associated with the South Carolina data where the range is from 44.5 to 24,200 square kilometers and the median size is 653 square kilometers. The larger drainage areas associated with the three NBSD data imply larger and more complex river channels that could increase the potential for turbulence and secondary flow patterns which could possibly increase scour potential. Additionally, these data points are associated with larger pier widths having complex pier foundations and the limited notes in the NBSD suggest that the pier footings were possibly exposed at the time of the scour measurement, thus potentially increasing the pier-scour depth. The limited notes also indicate that these piers were located in zones of contraction scour suggesting that the measured scour may be influenced by contraction scour in addition to local pier scour. While the field notes are inconclusive, they suggest some possible explanation of why these 3 data points exceed the South Carolina data.

The envelope curve for the South Carolina data in Figure 4 provides a useful supplementary tool for evaluating the potential for live-bed pier scour in South Carolina. For a more conservative evaluation of scour, the envelope curve for the NBSD data can be used. However, the limitations and uncertainty associated with the data used to develop these envelope curves will introduce some uncertainty. Therefore, caution and judgment must be used when applying them. Benedict and Caldwell (2009) provide additional information on the envelope curves regarding their development, limitations, and application.

\section{CONCLUSIONS}

A GPR system can be a useful tool to measure historic live-bed scour depths within stream channels. Data from such a system can be used to approximate the regional range and trend for scour that can be used for developing regional bridgescour envelope curves. For the case of live-bed pier scour, the South Carolina data show similar trends to laboratory and other field data indicating that the South Carolina data are reasonable and can be used to assess the performance of scourprediction equations to develop regional envelope curves. These envelopes can help engineers assess the reasonableness of predicted scour and the potential for scour within a region of interest. Historic scour data measured with a GPR system will always have error and uncertainty associated with them, and this should be kept in mind when using these data to assess historic scour patterns. Additional information regarding the development, limitations, and application of the envelope curves can be found in Benedict and Caldwell (2009). 


\section{REFERENCES}

Benedict, S.T. (2003). Clear-water abutment and contraction scour in the Coastal Plain and Piedmont Provinces of South Carolina, 1996-99. U.S. Geological Survey Water-Resources Investigations Report 03-4064, 137 p.

Benedict, S.T. (2007). "Development of regional envelope curves for assessing limits and trends in scour." Proceedings of The 2007 World Environmental and Water Resources Congress, Tampa, Florida, (CD-ROM) American Society of Civil Engineers, Reston, Virginia.

Benedict, S.T., and Caldwell, A.W. (2006). Development and evaluation of clearwater pier and contraction scour envelope curves in the Coastal Plain and Piedmont of South Carolina. U.S. Geological Survey Scientific Investigations Report 2005-5289, 98 p.

Benedict, S.T. and Caldwell, A.W. (2009). Development and evaluation of live-bed pier and contraction scour envelope curves in the Coastal Plain and Piedmont provinces of South Carolina. U.S. Geological Survey Scientific Investigations Report 2009-5099, 108 p.

Laursen, E.M., and Toch, A. (1956). Scour around bridge piers and abutments. Iowa Highway Research Board, Bulletin No. 4, 60 p.

Melville, B.W. and Coleman, S.E. (2000). Bridge Scour. Highlands, Colorado, Water Resources Publications, LLC, 550 p.

Mueller, D.S., and Wagner, C.R. (2005). Field observations and evaluations of streambed scour at bridges. Federal Highway Administration, Publication FHWA-RD-03-052, $122 \mathrm{p}$.

Placzek, Gary, and Haeni, F.P. (1995). Surface-geophysical techniques used to detect existing and infilled scour holes near bridge piers. U.S. Geological Survey, Water-Resources Investigations Report 95-4009, 44 p.

Richardson, E.V., and Davis, S.R. (2001). Evaluating scour at bridges. Federal Highway Administration Hydraulic Engineering Circular No. 18, Publication FHWA-NHI-01-001, 378 p.

U.S. Geological Survey. (2001). National Bridge Scour Database, accessed October 15, 2008, at http://water.usgs.gov/osw/techniques/bs/BSDMS/index.htm

Wagner, C.R., Mueller, D.S., Parola, A.C., Hagerty, D.J., and Benedict, S.T. (2006) "Scour at contracted bridges." Transportation Research Board. National Cooperative Highway Research Program Document 83 (Project 24-14), 299 p., accessed December 19, 2008, at http://onlinepubs.trb.org/onlinepubs/nchrp/nchrp w83.pdf

Webb, D.J., Anderson N.L., Newton T., and Cardimona S. (2000). "Bridge scour: Application of ground penetrating radar." Federal Highway Administration and Missouri Department of Transportation special publication. (http://utc.mst.edu/documents/scour.pdf accessed March 2, 2010). 